Fikrah: Jurnal Ilmu Aqidah dan Studi Keagamaan

issn 2354-6174 eissn 2476-9649

Tersedia online di: journal.iainkudus.ac.id/index.php/fikrah

Volume 8 Nomor 12020 , (1-24)

DOI: $10.21043 /$ fikrah.v8i1.7060

\title{
Modernitas Pesantren dan Kesakralan Pernikahan dalam Upacara Rahmat Pura
}

\author{
Iin Nur Zulaili \\ Diaspora Muda Lamongan, Jawa Timur, Indonesia \\ iinzulaili13@gmail.com
}

\begin{abstract}
Abstrak
Fenomena nikah massal memang sering terjadi di Indonesia, namun nikah massal yang dilakukan dengan upacara-upacara tertentu ternyata menyuguhkan perilaku beragama yang berbeda di lapisan masyarakat. Tulisan ini mengkaji tentang festival "Rahmat Pura" yang diselenggarakan oleh Yayasan SPMAA (Sumber Pendidikan Mental Agama Allah) di Lamongan setiap satu tahun sekali. Teori modernisasi akan menelisik bagaimana tradisi upacara Rahmat Pura ini berlangsung dan bertahan di era modern ini. Penulis menggunakan metode kualitatif yakni melakukan wawancara intensif dengan penyelenggara juga peserta festival. Hasil dari penelitian ini menunjukkan bahwa keterkaitan keterikatan antara santri dan pengabdian untuk pesantren di era modernitas Islam masih menjadi tradisi yang dipertahankan.
\end{abstract}

Kata kunci: etika sosial, perilaku beragama, Rahmat Pura, santri muslim. 


\begin{abstract}
The phenomena of Mass Marriage is often the case in Indonesia, but the mass marriage with a certain ceremony has been different presented of religious behavior in the community layer. This article discusses about "Rahmat Pura" festivals organized by SPMAA Foundation in Lamongan once a year. The Modernization theory will be examining by the tradition of Rahmat Pura, which is the processing, lasting, and enduring in this modern era. The autors use qualitative methods of conducting intensive interviews with organizers as well as festival participants. The results showed that the interconnectedness between students (santri muslim) and the devotion for pesantren in the era of Islamic modernity remains a preserved tradition.
\end{abstract}

Keywords: Rahmat Pura, religious behaviour, social ethics, santri muslim.

\title{
Pendahuluan
}

Masyarakat Muslim di Indonesia seringkali mengadakan pesta pernikahan dengan prosesi adat yang beranekaragam. Tentunya acara prosesi pernikahan atau yang populer di masyarakat disebut dengan pesta perkawinan merupakan perwujudan rasa syukur kepada Allah SWT. sekaligus memberikan kabar gembira kepada kerabat. Bagi kebanyakan orang, pesta pernikahan merupakan puncak kebahagiaan karena pada hari itu pengantin dinobatkan sebagai raja dan ratu sehari. Dalam melaksanakan pesta perkawinan idealnya cukup dengan mengundang sanak kerabat dan tetangga terdekat. Akan tetapi, jika mengadakan pesta perkawinan yang dijalankan oleh lebih dari satu pasangan dan melakukan upacara dalam prosesi akadnya tentu menarik untuk dibicarakan.

Dalam Islam, konsep pernikahan sangat diperhatikan secara detail, selain menikah merupakan sunnah Nabi Muhammad Saw. juga karena pernikahan dipandang sebagai kemaslahatan umum, sebab kalau tidak ada pernikahan, manusia tidak akan mengenal satu sama lain dan keberlangsungan hidup akan punah. Pernikahan juga berguna dalam memelihara kerukunan, menghindari timbulnya perselisihan, menjauhkan permusuhan antar sesama dan menumbuhkan ruang sosial yang terstruktur (Haq, 2019, hal. 32).

Jika ditelisik dari beberapa pesantren yang tersebar di wilayah Indonesia, tradisi pernikahan dari hasil perjodohan bukan sebuah keniscayaan, namun ada beberapa pesantren yang tidak memakai upacara dan pernikahan secara besar yang dilakukan oleh beberapa pasangan. Tradisi perjodohan oleh keluarga pondok pesantren memang sudah menjadi budaya pesantren, hal itu terjadi karena kesetiaan atau ketaatan seorang santri 
kepada pondok atau kiainya. Hal tersebut sekaligus juga menjadikan santri untuk berperan melanggengkan pengabdian kepada pondok pesantren yang telah mendidiknya.

Dalam artikel ini, penulis tertarik untuk mengangkat tentang proses upacara Rahmat Pura dan proses perjodohannya di Yayasan Sumber Pengajaran Mental Agama Allah (SPMAA) Turi Lamongan Jawa Timur. Penulis memfokuskan pada proses perjodohan, karakteristik calon pengantin untuk mengikuti proses upacara serta pengabdian yang harus dilakukan oleh seluruh pasangan yang telah melakukan upacara pernikahan Rahmat Pura. Yayasan ini berdiri pertama kali pada tanggal 6 Januari 1961 dan saat ini memiliki 56 cabang di seluruh Indonesia.

Sebagai lembaga independen, pesantren memilih dan menerapkan ideologi yang ditransformasikan kepada para santrinya, termasuk diantaranya pengkaderan santri melalui jalur perjodohan, menikahkan sampai pada keteraturan kontrol pengabdian. Dalam konteks ini, pesantren sekilas menjadi praktek pengekangan pada rasa individualisme santri, namun secara aspek keagamaan, dengan proses seperti inilah kerberlanjutan sebuah pesantren untuk menjadi lembaga yang mengikuti modernitas zaman semakin diakui. Hal ini disebabka pengkaderan santri sampai jenjang pernikahan tanpa jalur pemaksaan tentu bukan untuk merusak nilai-nilai keteraturan dalam pendidikan Islam pesantren, melainkan akan menjadikan sistem pendidikan pesantren menjadi lebih modern dan menyuarakan keaktifan suatu pesantren dalam struktur pengabdian santri.

Selanjutnya yang patut di sadari pula bahwa antara berbagai pesantren yang berbasis ideologis santri di Indonesia relatif memiliki kekhasan seiring perbedaan latar belakang pesantren juga pendidikan informal yang diajarkan. Ditambah faktor ideologi pesantren yang menjadikan santri sebagai bagian dari pesantren itu sendiri. Pesantren SPMAA misalnya, mengklaim diri sebagai pesantren yang tidak hanya fokus pada pengkaderan santri namun juga berkecimpung pada kemandirian pesantren dengan keterlibatan penuh santri-santrinya.

Di antara fokus pendidikan di sebuah pesantren tidak hanya berdimensi pendidikan keagamaan saja tetapi juga bersifat sosial. Termasuk yayasan sekaligus pesantren SPMAA yang menggerakkan santrinya agar peka pada pendidikan sosial dimana santri menjadi pelaku sekaligus pemain di dalamnya. Di dalam term modernitas, tradisi-tradisi baik bisa runtuh karena 
pengaruh globalisasi atau modernisasi itu sendiri. Namun hal tersebut dapat dipertahankan dengan penerapan nilai-nilai Islam. Bagi seorang Muslim, modernisasi harus dipandang secara aktif dengan cara turut ikut mengambil peran di dalamnya, sehingga sebutan "agents of modernization" tidak hanya sebagai sebutan praktis namun juga diterapkan dalam kehidupan sehari-hari. Misalnya nilai-nilai ajaran Islam untuk kerja keras, penghargaan yang tinggi terhadap waktu, pendidikan, sikap ekspertis pentingnya kemampuan teknis dan keahlian dan demokrasi yang juga termasuk dalam sikap modern (Asry, 2019, hal. 133).

\section{Perubahan Sosial}

Teori modernisasi penulis gunakan dalam merubah paradigma masyarakat menjadi lebih baik dalam hal kehidupan sosial ekonomi. Perubahan tersebut berkaitan dengan perubahan dari struktur sosial (polapola perilaku dan interaksi sosial). Perubahan sosial dalam hal ini yang terjadi melekat pada kehidupan sosial suatu masyarakat, termasuk juga pada diri individu yang mengalami modernisasi tingkat individu (Suaidi, 2014, hal. 55). Dari sinilah modernisme hadir karena terdapat tradisi yang harus dilanjutkan atau dilanggengkan, sehingga saat tradisi upacara pernikahan Rahmat Pura dilanggengkan, secara tidak langsung menjadi termasuk dalam konsep modernitas Islam.

Menurut Lenawati (2019, hal. 132), teori modernisasi jika ditekankan pada faktor internal dan motif psikologi, maka dapat menggerakkan kebutuhan prestasi, keinginan untuk berbuat sesuatu dengan lebih baik, adanya keadaan lebih untuk berkembang dalam transisi ke modernitas melalui pendidikan. Sarana pendidikan di sini penulis kaitkan pada Yayasan SPMAA itu sendiri sebagai fasilitator penyedia sekaligus penggerak tradisi upacara pernikahan Rahmat Pura yang dilangsungkan setiap tahunnya untuk seluruh santri yang telah pantas mengikutinya. Dalam Islam juga sangat menganjurkan untuk modernisasi yakni menghendaki agar setiap manusia mempunyai sifat maju ke dapan untuk lebih baik, namun tetap mengacu pada koridor konsep al-Quran, hadis dan ijtihad.

Berbeda dengan pandangan Jalil (2017, hal. 116) yang menyatakan bahwa modernitas yang diiringi dengan globalisasi dikhawatirkan akan menjadi cara dalam meruntuhkan nilai-nilai luhur sebuah peradaban tradisional. Namun di sisi lain akan menjadi cara untuk melahirkan dunia baru yang disebut sebagai postmodernisme. Melihat penjelasan artikel di atas, 
tulisan ini mengajak pembaca untuk mengetahui bahwa ketika modernitas Islam dihadirkan dalam suatu tatanan pendidikan, nilai-nilai Islam menjadi penyatu antara aspek modernitas juga secara tidak langsung aspek tradisional suatu budaya masyarakat. Oleh karena itu, tradisi kesakralan pernikahan upacara Rahmat Pura yang dikembangkan oleh SPMAA tetap berlangsung di setiap tahunnya walaupun kehadiran modernisasi berada di tengah sistem pendidikan mereka.

Sedangkan Yunus (2019, hal. 115) berbicara tentang pesantren yang menggunakan kaidah "al-Muhaafadhatu alal al-Qadim al-Shalih wa alAkhdzu bi al-Jadid al-Ashlah", yakni suatu pesantren yang tetap memelihara tradisi lama yang masih cocok dan mengadopsi inovasi baru yang lebih cocok lagi. Dalam hal ini pesantren SPMAA termasuk ke dalam pesantren yang masih mempertahankan kaidah tersebut, namun tidak dengan cara memasukkan kurikulum baru yang modern terlebih kepada mempertahankan tradisi lama yang masih cocok diterapkan oleh pesantren seperti upacara pernikahan Rahmat Pura tersebut.

Penulis menghubungkan dengan pola dasar pendidikan Islam yang ideal, bahwa dalam pendidikan pragmatik memandang manusia sebagai makhuk hidup yang membutuhkan sesuatu untuk melangsungkan kehidupannya baik bersifat jasmani maupun rohani (Syahminan, 2014, hal. 250). Pesantren SPMAA tidak memandang ada perbedaan jauh antara santri dan keluarga pesantren. Apabila terdapat keluarga pesantren yang menjadi peserta upacara Rahmat Pura maka akan diberlangsungkan bersamaan dengan upacara para santri. Selain melakukan wawancara intensif dengan penyelenggara juga peserta upacara Rahmat Pura, penulis juga mengamati melalui media sosial di YouTube, pakaian yang dikenakan dalam upacara pernikahan terdapat perbedaan antara keluarga pesantren dengan santri yang menjadi peserta Rahmat Pura.

\section{Metode}

Penulis menggunakan penelitian kualitatif yang jenis penelitiannya adalah fenomenologis. Penulis melakukan wawancara intensif dengan penyelenggara juga peserta upaca Rahmat Pura. Pendekatan kualitatif ini mencoba untuk menerjemahkan pandangan-pandangan dasar interpretif yang merupakan realitas sosial yang subjektif dan tidak terlepas dari individu atau subyek yang terlibat. Karakteristik subyek yang diperlukan untuk menyelesaikan penelitian ini adalah: pertama, seseorang yang telah menikah 
dan pernah mengikuti Upacara Rahmat Pura. Kedua, seseorang yang belum menikah dan belum mengikuti proses Upacara Rahmat Pura. Ketiga, berdomisili di yayasan SPMAA Pusat, yakni di Turi Lamongan. Meskipun penelitian ini bersifat lapangan, namun tidak menafikan menggunakan referensi dalam bentuk bacaan jurnal yang berkaitan dengan tema penelitian, untuk mendukung data pada saat wawancara. Selain itu, penelitian ini juga menggunakan data primer dari para responden yang merupakan subjek yang memberikan informasi serta pengalaman pada saat mengikuti upacara Rahmat Pura pesantren SPMAA.

\section{Hasil dan Pembahasan}

Terdapat tiga responden dalam penelitian ini antara lain: (1) B, lakilaki, pengurus Yayasan SPMAA berusia 39 tahun berstatus sebagai Direktur Operasional Yayasan, memiliki dua istri dan pernah mengikuti pernikahan masal bersama dengan santri Yayasan SPMAA. (2) L, perempuan 22 tahun, menjadi santri SPMAA selama 5 tahun, telah mengikuti Upacara Rahmat Pura pada tahun 2018. (3) W, 22 tahun, status di yayasan SPMAA ialah menjadi Taruni, belum menikah (sudah pantas untuk diikutkan Upacara Rahmat Pura). Taruni adalah tingkatan di atas seorang santri yang telah menyelesaikan pengabdiannya di pondok selama dua tahun setelah melaksanakan sekolah Madrasah Aliyah. Responden di atas, dua orang pernah mengikuti upacara Rahmat Pura dan satu pernah mengikuti pernikahan massal, sebelum tradisi upacara Rahmat Pura disahkan. Dua orang yang telah mengikuti Rahmat Pura mempercayai bahwa menjadi peserta upacara Rahmat Pura adalah sebuah penghargaan. Mereka diberikan perasaan seperti keluarga sendiri oleh pesantren, hal tersebut menjadi suatu kebanggan bagi seorang santri.

Dalam kontek ini, B adalah seorang yang berasal keluarga pesantren. B juga merasakan mengikuti pernikahan massal bersamaan dengan santri lainnya. B juga dijodohkan atas saran dari keluarganya. Tanpa penolakan B memenuhi perjodohan tersebut. Bagi B perjodohan tersebut adalah amanah dan mandat terbaik dari keluarganya. Pasangan yang dipilihkan oleh keluarganya adalah berlatar belakang pendidikan yang sedang dibutuhkan oleh pesantren. Pada saat nikah massal, upacara Rahmat Pura belum ada, masih pada pernikahan massal saja. B saat ini menjadi pelaksana ritual saat ada santri yang menjadi peserta upacara Rahmat Pura. 
L menyatakan bahwa mengikuti upacara Rahmat Pura juga merupakan penghormatan bagi dirinya yang merupakan santri. L tergolong masih berusia muda, namun ia dan keluarganya memutuskan menerima kesempatan untuk menjadi santri selamanya di pesantren SPMAA. L dan keluarganya menerima secara utuh semua keputusan dari pesantren. Keluarga L menganggap bahwa semua guru di pesantren $\mathrm{L}$ adalah orang tua kedua bagi L, sehingga apapun pilihan dari pesantren terhadap L didukung penuh oleh keluarga L. Setelah menikah L dan suaminya tidak langsung tinggal satu rumah karena persediaan rumah masih terbatas oleh pesantren. Namun L dan suami menerima keputusan tersebut dengan alasan pengabdian. L menganggap bahwa pernikahan ini adalah rahmat, sebagai santri yang sudah berkeluarga, L menilai bahwa ia dan suaminya adalah partner yang keberadaan mereka di pesantren tersebut sangat berperan dan dibutuhkan. Ia tidak merasa tertekan dan rindu karena masih bisa bertemu sewaktu-waktu. Kemudian, W adalah santri Taruni yang dipandang telah siap untuk diikutkan sebagai peserta upacara Rahmat Pura. W telah mengabdikan diri pada pesantren dua tahun. W mengatakan bahwa ia siap untuk menjadi peserta dan menerima calon yang dipilihkan oleh keluarga pesantren. Lagi lagi, W menganggap bahwa keputusan pemilihan calon suami untuknya adalah suatu penghargaan dan penghormaan atas dirinya sebagai santri di pesantren SPMAA.

Ketiga responden yang telah penulis amati, masing-masing berstatus sebagai santri mempunyai harapan yang besar kepada pesantren yang telah mendidiknya. Yayasan SPMAA membuat program ini sebagai rangkaian proses pendidikan dari Pondok Pesantren SPMAA untuk santri yang telah selesai mengabdikan diri di pesantren. Selain menjadi proses pembelajaran, rangkain upacara Rahmat Pura juga menjadi bagian dari proses pembelajaran santri. Dalam programnya, proses penawaran kepada santri yang telah siap menikah dilakukan dan juga atas persetujuan kedua keluarga. Dalam proses perjodohan, kedua calon mempelai tidak diperbolehkan bertemu, kecuali pada saat pendidikan pra-nikah selama kurang lebih satu minggu oleh yayasan SPMAA. Namun, terdapat pertemuan berkala antar pasangan yang juga tetap diawasi oleh mentor dari yayasan. Adanya amalan-amalan yang diharuskan pesantren untuk diamalkan seorang santri di sebuah pesantren, menjadikan perubahan pola perilaku dan interaksi sosial seorang santri kepada ruang kehidupan sosialnya. 


\section{Upacara Rahmat Pura}

Awal mula pernikahan massal tidak memakai adat upacara dan ramairamai, hanya dilaksanakan seperti pernikahan massal pada umumnya. Akan tetapi, pada tahun 2013 upacara Rahmat Pura mulai diperkenalkan di masyarakat secara resmi. Seperti yang dilakukan pada saat pernikahan Tentara Nasional Indonesia yang bertemakan Pedang Pora, yayasan ini berinisiatif menamai upacara pesantren dengan nama Rahmat Pura. "Rahmat" bermakna pernikahan yang dipenuhi dengan rahmat Allah serta karunia nikmat yang telah diberikan kepada seluruh keluarga pengantin dan keluarga besar pesantren. Sedangkan "Pura" bermakna gapura, di mana sebelum melaksanakan akad nikah, semua calon pengantin putra dan putri akan melewati santri yang menjadi gapura saat prosesi upacara pernikahan.

Rahmat Pura adalah salah satu ritual dalam upacara perkawinan di Pesantren SPMAA, yang dilaksanakan sebelum upacara akad nikah berlangsung. Upacara Rahmat Pura adalah salah satu produk budaya, yang saat ini masih dilestarikan oleh Yayasan SPMAA. Pada prinsipnya upacara ini menjadi tradisi pesantren setiap satu tahun sekali, namun apabila ada beberapa pasangan yang telah siap menikah, dalam satu tahun bisa terjadi dua kali upacara Rahmat Pura. Upacara yang diselenggarakan sebelum akad nikah berlangsung ini mempunyai makna yang dalam. Di balik upacara ini semua peserta, panitia dan keluarga yayasan dianjurkan untuk menjalankan puasa. Puasa tersebut diartikulasikan sebagai salah satu ikhtiar bagi pasangan yang menikah untuk sabar dan kuat nanti menghadapi bahtera kehidupan baru dalam keluarga mereka.

Upacara Rahmat Pura dimulai dan diawali dengan salat Duha berjamaah oleh seluruh peserta yang akan menikah. Setelah itu para peserta Rahmat Pura berjalan sesuai tempatnya, bagi laki-laki dari tempat laki-laki dan perempuan dari tempat perempuan. Pemimpin ritual (seorang gus atau pengurus yayasan) membaca Surat al-Mulk kemudian diikuti oleh seluruh peserta nikah dan jamaah yang hadir di tempat. Setelah membaca ayat suci alQuran, acara dilanjutkan dengan menyanyikan lagu Indonesia Raya. Dalam prosesi upacara seluruh pasangan nikah berlangsung, suasana upacara diiringi dengan lantunan bacaan asmaul husna. Sebelum semua calon mempelai dipanggil untuk melaksanakan akad, para gus (anak kiai) membacakan laporan mengenai penugasan (baik tempat dan lama waktu penugasan) yang pernah dilakukan oleh para taruna dan taruni. Produk 
Rahmat Pura Ma'had SPMAA ini dijadikan sebagai gerbang nyantri tahap kedua. Gerbang yang dimaknakan selain penuh rahmat dan rasa kesyukuram, gerbang Pura ini juga diartikan sebagai rahmat penugasan kembali. Bahwa tugas menjadi santri akan terus dipikul sampai wafat. Formasi gapura itu juga dilandaskan sebagai bentuk penghormatan kepada santri atas pengabdiannya selama mengabdi di pesantren SPMAA.

Pembelajaran lainnya dari upacara ini juga untuk santri-santri yang masih junior. Santri-santri junior diharapkan berpartisipasi dan menjadi tim penyelenggara dan petugas upacara Rahmat Pura supaya dapat melihat dan mengikuti ritual tersebut secara penuh dan utuh. Para gus yang mengawal secara teratur mengiringi para pengantin Rahmat Pura, di mana satu gus berada di depan dan gus lainnya berada di posisi di belakang. Ide dan pelaksanaan dalam prosesi upacara Rahmat Pura ini adalah new branding yang meneruskan warisan dari Bapak Guru Muhammad Abdullah Muchtar selaku pendiri Yayasan SPMAA. Oleh seluruh putra putrinya sebagai penerus pesantren di Lamongan dan cabang kota lainnya tetap melestarikan dan memberikan konsep baru dalam pernikahan massal ini. Menurut pesantren, konsep menikah tidak hanya dianggap sebagai setengah ibadah agama saja, namun juga sebagai syukuran agama. Maka dari itu menyelenggarakan pesta berbentuk upacara Rahmat Pura adalah upacara yang banyak dinantikan oleh santri SPMAA itu sendiri, karena sebagian besar pendapat dari mereka menganggap itu sebagai suatu kehormatan dari pesantren terhadap pengabdian mereka sebagai santri.

\section{Strategi Nyantri Tahap Kedua}

Menurut penuturan Gus Basyirun Adhim (Pengasuh Yayasan SPMAA divisi Operasional), seorang santri tidak hanya berhenti pada saat ia di wisuda kelulusan Madrasah Aliyah. Akan tetapi, santri itu akan terus menjadi santri sampai ia dipanggil menghadap Tuhannya (wafat). Doktrin yang diberikan pada saat pra nikah bahwa nanti semua pasangan ketika sudah menikah akan menjadi "Teman Satu Visi". Artinya seluruh pasangan akan merasakan bagaimana rasanya ditinggal jauh, seperti perasaan Siti Hajar ditinggalkan oleh Nabi Ibrahim. Pengabdian seluruh pasangan yang telah melakukan prosesi Rahmat Pura akan ditempatkan tugas mengajar di beberapa cabang yayasan SPMAA, dengan konsdisi harus siap kapan pun saat dipanggil.

Pengabdian ini tidak bisa ditolak karena sudah terikat dengan yayasan, penugasan dan penempatan untuk mengajar di wilayah cabang harus dalam 
keadaan siap sedia. Semua pasangan upacara Rahmat Pura dianjurkan untuk dapat merasakan bagaimana rasanya pernikahan jarak jauh. Tema yang diambil dalam penggambaran upacara Rahmat Pura ini seperti "Berkeluarga, Beragama, Melahirkan Santri Pembibit Keturunan Generasi Mujaddid". Dari pemilihan jodoh yang dipilihkan oleh gus dari keluarga pesantren, diharapkan setiap pasangan memiliki pernikahan dengan fungsi keluarga yang baik karena dalam sebuah pesantren proses pengkaderan santri yang berhasil ialah sampai jenjang pernikahan antar kader. Menurut pernyataan Gus Naim terdapat beberapa pertimbangan yang dijadikan acuan dalam penentuan kecocokan pasangan antara lain: geografis, kemampuan, karakter masingmasing santri, dan latar belakang keluarga. Dengan melihat empat pertimbangan di atas, para gus akan mudah menjodohkan santri satu dengan lainnya untuk diikutkan dalam upacara Rahmat Pura.

Yayasan SPMAA sudah melaksanakan proses ini sejak tahun 1980-an, namun baru membuat istilah upacara Rahmat Pura pada tahun 2013. Setiap pasangan yang akan melakukan upacara Rahmat Pura memang tidak saling bertemu satu sama lain. Karena dianjurkan untuk bertemu setelah melakukan akad pernikahan. Namun pesantren ini tidak memaksa apabila di tengah jalan proses taaruf tersebut terdapat salah satu pihak yang ingin berhenti maka diperbolehkan. Apabila dilihat tentang deskripsi modernitas yang memiliki nilai fundamental seperti, mengutamakan penilaian berdasarkan keberhasilan dan prestasi, bukan status (Ja'far, 2013, hal. 19). Maka santri dilihat dari kepantasan menikah karena memiliki keberhasilan menyelesaikan pengabdian selama satu tahun di pesantren. Hal tersebut yang dilihat dan menjadi suatu kesepakatan oleh pesantren kepada santri yang memenuhi syarat untuk menikah.

Pemberdayaan santri tahap kedua ini sejalan dengan fungsi dan peran dari sebuah pesantren. Pesantren SPMAA menjalankan peran tidak hanya sebagai pesantren dari sudut pandang ilmu pengetahuan salaf, namun juga menerapkan sudut pandang pesantren khalaf. Artinya pesantren sudah kooperatif terhadap perkembangan kemajuan ilmu pengetahuan dengan melibatkan teknologi. Misalnya dalam ritual upacara Rahmat Pura, keterlibatan santri untuk merekam, mengambil foto dan mendokumentasikan semua hal yang berkaitan dengan upacara disediakan oleh pesantren, sehingga masyarakat umum yang belum mengetahui upacara Rahmat Pura dapat melihat dan mencermati melalui media sosial YouTube. 


\section{Jenjang Perkawinan Tenaga Penyayang Umat (TPU)}

Kategori santri yang dapat mengikuti upacara Rahmat Pura minimal harus mengamalkan 8 amalan santri antara lain: salat Tahajud, salat Duha, salat berjamaah lima waktu, ngaji Ahad dan Jum'at, kajian Tafsir Hadis dan Quran, puasa Hari Senin dan Kamis, mengikuti majelis ilmu dan renungan suci. Apabila terdapat santri atau taruni yang tidak mengamalkan delapan amalan pesantren maka dapat dikategorikan sebagai "santri horor" dan wajib melaksanakan dan mengikuti pembinaan dari pesantren.

Taruni (satu tingkatan di atas santri/santri yang telah mengabdi selama dua tahun) dan telah mengikuti upacara Rahmat Pura akan menyandang gelar baru yakni sebagai Tenaga Penyayang Umat (TPU). TPU yang telah menikah dan sedang menjalankan pengabdian, tetap dalam kontrol dan pengawasan seluruh dewan pengurus pesantren. Dalam hal ini terdapat empat aspek yang digunakan untuk melihat keseriusan para TPU yaitu: pertama, umat, dilihat dari keseharian ia bersama masyarakat. Kontrol dari pengawas pusat kepada masyarakat setempat tentang pengabdian diri santri yang ditugaskan di salah satu cabang pesantren SPMAA. Kedua, giat, mencakup kajian-kajian sore dan kedisiplinan salat malam di pesantren. Ketiga, tempat, apakah tempatnya semakin tidak kondusif untuk dijadikan pembelajaran dan menuntut ilmu atau semakin baik. Keempat, alat, apakah persedian alat untuk mengajar atau penugasan itu lengkap atau banyak yang hilang. Standar ukuran TPU ini jika keluar dari standarisasi santri yang mengabaikan delapan amalan pesantren maka akan masuk pada kategori santri bina, dalam konsep ini ada penurunan grade dari pengasuh pesantren SPMAA sendiri, di mana dari TPU akan menjadi santri bina jika diketahui mengabaikan amalan santri dari pesantren.

Sebelum mengikuti kegiatan upacara Rahmat Pura terdapat prosesi sebelumnya. Bagi santri yang telah nyantri lama (minimal 2 tahun) maka akan bisa langsung dicarikan calon pasangan oleh pihak pengurus pesantren, akan tetapi bagi calon peserta yang berasal dari luar pesantren SPMAA akan mengikuti tes terlebih dahulu. Salah satu komitmen yang ditawarkan oleh pesantren ialah peserta menawarkan dirinya untuk pesantren "Saya mewakafkan diri untuk SPMAA". Dengan demikian, pihak yayasan akan mencarikan pasangan yang sesuai dengan calon peserta. Dalam konteks ini, terdapat konsekuensi yang harus dipersiapkan oleh calon peserta upacara 
Rahmat Pura di mana harus siap dipanggil ke mana pun, kapan pun dan di mana pun sesuai tugas pesantren.

Dalam tradisi pesantren, budaya pernikahan antar pesantren memang sudah biasa, namun dalam ranah struktural menjadikan pesantren juga membangun jaringan pada masyarakat sekitarnya. Santri yang pandai biasanya akan dijadikan menantu untuk memenuhi kebutuhan masingmasing cabang pesantren. Melalui pernikahan-pernikahan tersebut, upaya pesantren dalam mempertahankan jaringan sosialnya untuk membentuk jaringan sosial yang baru dan membuat semakin kuat (Salehudin, 2016, hal. 213). Jaringan sosial yang terbentuk antara pendiri maupun pengurus yayasan tercipta dari hubungan emosional yang dekat. Dalam hal ini tidak hanya melalui proses pendidikan, namun juga melalui proses perkawinan hubungan antar pengurus dan santri terjalin lebih luas.

\section{Modernitas Pesantren dalam Upacara Rahmat Pura}

Tradisi yang terjadi dalam upacara Rahmat Pura diperlihatkan tentang kesederhanaan dalam melakukan pesta pernikahan. Dalam mendapatkan kesakralan pernikahan, yayasan tidak menganjurkan untuk melakukan pesta secara mewah, karena tujuannya sebagai tanda kesyukuran agama. Dalam upacara seluruh biaya dari masing-masing pasangan ditanggung oleh pesantren SPMAA, dari mahar, pengembalian ngunduh mantu sampai pada acara resepsi dan makan-makan untuk tamu undangan. Suatu pesantren yang dalam perencanaan, pengorganisasian, pengarahan dan pengawasan lembaganya dengan sistem yang baik dapat dikategorikan masuk dalam tantangan modernitas pesantren (Krisdiyanto et al., 2019, hal. 19). Tampak ekspresi keagamaan yang ditampilkan dalam upacara Rahmat Pura (baik penerapan puasa kepada seluruh peserta maupun lantunan ayat-ayat suci alQuran oleh seluruh jamaah yang hadir) dapat dimaknai sebagai bentuk peningkatan religiusitas, juga dapat dimaknai sebagai bentuk era rekonstruksi agama atau menurut Wasisto sebagai new age movement (Jati, 2016, hal. 176).

Namun yang penulis tekankan di sini pada aspek modernitas Islam. Beranjak dari pengertian modernisasi yakni bentuk perubahan sosial yang terarah (directed-change) yang didasarkan pada perencanaan (plannedchange), menjadikan modernisasi berkrakteristik gerak sosial (social mobility). Artinya terdapat peluang arah pola-pola baru melalui sosialisasi dan polapola perilaku yang terbentuk dari proses unsur sosial ekonomis dan psikologis masyarakatnya (Asry, 2019, hal. 128). Sedangkan modernitas merujuk pada 
suatu keadaan yang mengaju pada sikap hidup yang modern. Sehingga dapat dikatakan, dengan adanya modernisasi akan memunculkan modernitas dengan catatan sebuah komunitas menerapkan suatu pandangan modernisasi dengan tujuan untuk mencapai kemajuan hidup dalam berbagai bidang kehidupan (Ja'far, 2013, hal. 11).

Makna tradisi merupakan kebiasaan yang diwariskan antar generasi satu dengan generasi selanjutnya, maka dalam upacara pernikahan Rahmat Pura merupakan tradisi turun-temurun di Pesantren SPMAA. Kemudian, setelah tradisi upacara pernikahan tersebut diunggah ke media sosial YouTube, maka terjadi percampuran antara tradisi pernikahan secara Islami dan modernitas di kalangan pesantren.

Selama proses upacara Rahmat Pura, seluruh peserta sangat menekankan aspek-aspek syariat, mulai proses sampai pada ritual acara. Disinilah agama berperan penting untuk mempertahankan kedudukan dan peranan manusia dalam kehidupannya. Dalam konteks ini, Gramsci melalui teori hegemoninya bahwa seorang perangkat kerja beserta pranatapranatanya mampu membujuk masyarakat agar taat pada mereka melalui kehidupan beragama (Rahmaniah, 2014, hal. 443). Di samping itu, hegemoni yang terjadi dalam tatanan pesantren merupakan kekuasaan kehidupan beragama melalui persetujuan (konsensus), yang mana di dalamnya ada proses penerimaan antara intelektual dan emosional dari masing-masing pelaku untuk melanggengkan program yang dilaksanakan Lembaga pesantren (Rahmaniah, 2014, hal. 444).

Menurut Indah Arvianti bahwa dalam setiap pernikahan adat Jawa terdapat kesakralan dalam ritualnya. Falsafah dan makna yang terkandung di dalamnya baik menggunakan bahasa Jawa atau bahasa Indonesia dapat dijadikan pedoman dalam kehidupan berumah tangga (Arvianti, 2010, hal. 87). Begitupun dalam kesakralan upacara Rahmat Pura, dari dimulainya acara yang bertemakan seperti upacara pernikahan TNI-AD, namun dari tradisi keagamaan pesantren masih tetap diutamakan, seperti dilaksanakannya pembacaan ayat-ayat al-Quran sampai lantunan asmaul husna sebelum akad nikah dilangsungkan. Selain itu, sebelum upacara, proses penggunaan bahasa Indoensia dengan konsep "Siap-Sigap" seperti halnya laporannya TNI kepada komandan upacara. Sebagaimana yang disampaikan pengasuh pesantren, bahwa hal tersebut berkaitan erat dengan tugas yang hendak diemban oleh calon pengantin saat membangun bahtera rumah tangga, juga tetap menjalankan pengabdian kepada pesantren dan bersedia untuk ditempatkan di cabang pesantren yang ditunjuk SPMAA. 
Riset lain menyebutkan bahwa tingkat keberhasilan pada proses pernikahan dengan proses taaruf lebih tinggi daripada berpacaran terlebih dahulu sebelum menikah. Dapat disimpulkan bahwa pasangan yang menikah melalui taaruf karena beberapa motif antara lain; pengaruh lingkungan sekitar yang meliputi nilai-nilai Islam, tidak ingin mendapat pengaruh dampak buruk pacaran, dan keinginan untuk jangka panjang mengharapkan keberkahan dalam pernikahan tersebut (Hapsa et al., 2019, hal. 11). Riset Hapsa dan teman-temannya diterapkan juga dalam sistem perekrutan peserta upacara Rahmat Pura. Dalam penyeleksian peserta rahmat pura, calon peserta dilarang berpacaran dan harus berani memutuskan hubungan dengan pacarnya apabila hendak mengikuti upacara Rahmat Pura. Selain aturan tersebut dibuat untuk calon peserta Rahmat Pura, peraturan dilarang pacaran berlaku bagi santri pesantren SPMAA. Oleh karena itu, pembelajaran santri sejak dini diterapkan pesantren dengan dibuktikan keterlibatan para santri dan taruni dalam pelaksanaan upacara Rahmat Pura.

Rahmaniah (2014, hal. 244) menjelaskan dalam risetnya bahwa dalam pernikahan endogami yakni antar keluarga, antar marga atau kelompok sosial, akibat adanya modernisasi baik pengaruh budaya luar, pendidikan, sosial maupun ekonomi menjadikan perubahan pola pernikahan menjadi beralih ke pernikahan eksogami. Dalam hal tersebut tentu keduanya memiliki kekurangan dan kelebihan satu dengan lainnya. Berkaitan dengan perubahan sosial, bahwa tanda adanya modernisasi terjadi akibat adanya penerimaan inovasi, metode, isi materi dan manajemen pesantren (Ali \& Purwandi, 2016, hal. 304). Riset lainnya, religiusitas mempunyai peranan penting dalam membentuk sikap dalam pernikahan. Fungsi-fungsi keluarga dan kepuasan pernikahan akan lebih tinggi apabila seorang yang menikah melaksanakan ajaran agamanya dalam berbagai aktivitasnya (Latifa, 2015, hal. 21).

Proses keteraturan pesantren dalam mendidik santrinya sangatlah penting. Secara teoretis, pengabdian santri kepada pesantren tidak lain adalah untuk melanggengkan sebuah pesantren menuju pada titik modernitas Islam. Sebuah perubahan sosial dalam pesantren akan terlihat, jika mampu menampilkan sesuatu yang berbeda dengan pesantren lainnya. Tentunya berkaitan dengan sistem manajemen dan inovasi yang dikembangan oleh pesantren. Dalam hal perjodohan di struktural pesantren, baik antara santri dengan keluarga pesantren maupun antara kader santri, mampu merefleksikan komitmen beragama dari pesantren maupun santri. Komitmen tersebut terbentuk dari tingkatan kepercayaam, kejujuran dan pelaksanaan ajaran-ajaran agama pada kehidupan sehari-hari dalam lingkup pesantren. 


\section{Simpulan}

Modernitas Islam pada suatu pesantren sangat bergantung pada otoritas pemimpin pesantren. Suatu pesantren dapat dikatakan modern apabila ia telah memiliki daya pemikiran tidak hanya untuk perkembangan pesantren satu atau dua bulan saja, melainkan bagaiman cara mempertahankan pesantren untuk bisa mengikuti zaman tanpa harus meninggalkan keberlangsungan tradisi-tradisi dalam agam. Modernitas erat kaitannya dengan hal-hal yang baru berkembang. Di era digitalisasi saat ini, banyak pesantren yang menjadikan media sosial sebagai dakwah atas kegiatan yang berlangsung di pesantren. Di sisi lain sebagai tanda bahwa pesantren sedang 'mengikuti berkembangnya zaman', pesantren juga tampil dengan wajah baru di mana pesantren tetap bisa eksis dan melanjutkan tradisi pesantren dengan modernitas yang ada. Sebagaimana yang dilakukan Pesantren SPMAA menjadikan media sosial YouTube sebagai akses dakwah digital atas pelestarian tradisi Upacara Rahmat Pura. Implikasi positif dari kesakralan upacara Rahmat Pura bagi modernitas Islam adalah saat suatu pesantren menghendaki perubahan sosial dan inovasi dalam perkembangannya namun tetap berpedoman tatanan syariat. Pesantren SPMAA tidak menutup untuk menerima inovasi dan pengetahuan baru demi tetap terselenggaranya upacara pernikahan massal tersebut, baik di pusat maupun cabang pesantren SPMAA di Indonesia.

\section{Referensi}

Ali, H., \& Purwandi, L. (2016). 2020:The Urban Middle-Class Millennials. PT Alvara Strategi Indonesia.

Arvianti, I. (2010, September). "Metafora Tuwuhan dalam Budaya Pernikahan Adat Jawa". Majalah Ilmiah Informatika, 69-88.

Asry, L. (2019). Modernisasi dalam Perspektif Islam. At-Tanzir: Jurnal Ilmiah Prodi Komunikasi dan Penyiaran Islam, 1(2).

Hapsa, K. P., Wahyudin, U., \& Zein, D. (2019). "Perilaku Komunikasi dan Makna Samawa Pada pasangan Menikah Melalui Ta'aruf”. Jurnal Riset Komunikasi, 2(1), 1-12.

Haq, I. H. (2019). Nilai-Nilai Islam dalam Upacara Adat Pernikahan Sunda. Al-Tsaqafa: Jurnal Peradaban Islam, 16(1), 29-43. https://doi.org/10.1109/MTAS.2004.1371634

Ja'far. (2013). “Agama dan Modernitas”. Pena Per.

Jalil, A., \& Aminah, S. (2017). Resistensi Tradisi Terhadap Modernitas. Umbara: 
Indonesian Journal of Anthropology: Indonesian Journal of Anthropology, 2(2), 113126.

Jati, W. R. (2016). Aktivisme Kelas Menengah Berbasis Sosial Media: Munculnya Relawan dalam Pemilu 2014. Jurnal Ilmu Sosial Politik, 2o(2).

Krisdiyanto, G., Muflikha, M., Sahara, E. E., \& Mahfud, C. (2019). Sistem Pendidikan Pesantren dan Tantangan Modernitas. Tarbawi: Jurnal Ilmu Pendidikan, 15(1), 1121.

Latifa, R. (2015). Komitmen Beragama Islam Memprediksi Stabilitas Pernikahan. Tazkiya Journal of Psychology, 2o(1), 1-26. https://doi.org/10.15408/tazkiya.v20i1.9191

Rahmaniah, S. E. (2014). Multikulturalisme Dan Hegemoni Politik Pernikahan Endogami: Implikasi Dalam Dakwah Islam. Walisongo: Jurnal Penelitian Sosial Keagamaan, 22(2), 433-456. https://doi.org/10.21580/WS.22.2.273

Salehudin, A. (2016). Konstruksi Jaringan Sosial Pesantren: Strategi Eksis Di Tengah Perubahan. Religi Jurnal Studi Agama-Agama, 10(2), 204-216. https://doi.org/10.14421/rejusta.2014.1002-05

Suaidi, S. (2014). Islam Dan Modernisasi. Islamuna, 1(1), 49-61. https://doi.org/10.21143/jhp.vol1.no1.573

Syahminan, S. (2014). Modernisasi Sistem Pendidikan Islam di Indonesia pada Abad 21. Jurnal Ilmiah Peuradeun International Multidisciplinary Journal, 2(2), 235-260.

Yunus, M. (2019). Pesantren Sebagai Lembaga Pendidikan Islam Asli Indonesia. Edification, 1(1), 111-118. https://doi.org/10.1109/MTAS.2004.1371634 